\title{
Spring Creek Representative and Experimental Watershed Project
}

\author{
by Graham Hillman ${ }^{1}$ and Richard Rothwell ${ }^{2}$
}

\begin{abstract}
The Spring Creek Representative and Experimental Watershed Project was initiated in 1965 to understand the effects of land-use conversion from boreal forest to agricultural land on mid-size watersheds typical to northern Alberta. The initial project was deactivated in 1986 and the treatment was never completed. In 1991, Daishowa-Marubeni International Ltd. and the Alberta Department of Environmental Protection restarted the project with new objectives to determine the hydrologic effects of aspen harvesting and the hydrologic recovery of water yield post-harvest. The impacts of basin morphology and forest harvesting on water quality were also investigated. The objectives of this manuscript are to summarize the novel results and data collected for this project.
\end{abstract}

\section{RÉSUMÉ}

Le Projet de démonstration et de recherche de Spring Creek a été lancé en 1965 afin de comprendre les effets liés à la conversion d'un territoire en forêt boréale en une terre agricole sur les bassins versants détendue moyenne typique au nord de l'Alberta. Le projet initial a été abandonné en 1986 et le traitement n’a jamais été complété. En 1991, DaishowaMarubeni International Ltd. et l'Alberta Department of Environmental Protection ont redémarré le projet avec comme nouveaux objectifs de connaître les effets hydrologiques de la récolte du peuplier et de documenter le rétablissement hydrologique de l'apport en eau après la récolte. Létude portait également sur les effets de la morphologie du bassin et de lexploitation forestière sur la qualité de l'eau. Cet article fait la synthèse de résultats inédits et des données recueillies pour ce projet.

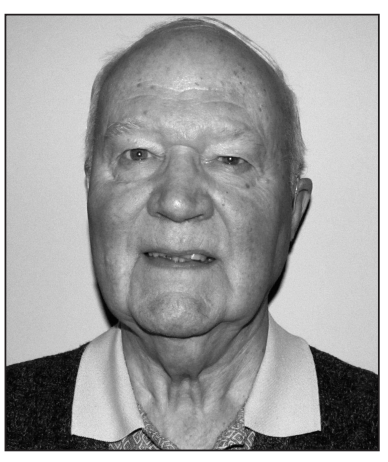

Graham Hillman

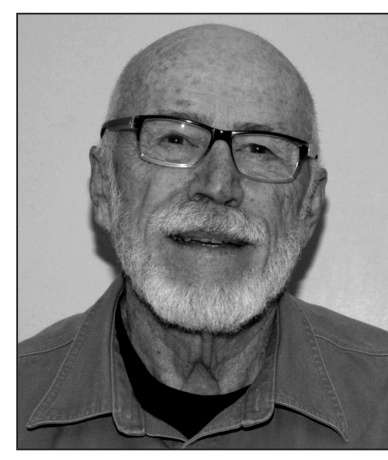

Richard Rothwell

\section{Introduction}

The Spring Creek Representative and Experimental Watershed Project was initiated in 1965 in response to the need for information on the effects of land-use conversion from boreal forest to agricultural land, regional hydrological data on midsize watersheds typical to northern Alberta (Table 1), and as a Canadian contribution to the International Hydrological Decade. When the project was initiated, two phases were outlined: 1) a before-treatment phase, in which the undisturbed watershed would be monitored and modeled to describe the hydrology of the basin; and, 2) an after-treatment phase, in which the effects of a large-scale conversion of boreal forest to agricultural land would be studied (Table 2). Unfortunately, in

1986 the project was deactivated and the treatment was never completed.

In 1991, the Spring Creek Project was restarted by a forestry company, Daishowa-Marubeni International Ltd. (DMI), and the Alberta Department of Environmental Protection. However, as the project was resurrected, the objectives changed to focus on determining the hydrologic effects of aspen harvesting and the hydrologic recovery of water yield post-harvest. The Canadian Forest Service (CFS) joined the project the following year and was particularly interested in the effects of the harvesting on water quality. In the winter of 1993/1994, 23\% of the Rocky Creek sub-basin was harvested, which consisted of clear-cut patches dispersed throughout the middle and lower sections of the sub-basin. Riparian areas were left intact with buffer strips of varying widths. The blocks did not encroach on the fen or the wetland in the center of the basin.

\section{Results}

\section{Pre-treatment results}

- Antecedent soil moisture caused significant differences in runoff response to precipitation events due to varying available water storage capacity (Holecek 1967, 1970).

- Wetlands have an effect similar to that of antecedent soil water on flow response, such that wetlands are able to absorb (or relay) water based on whether the wetland is below (or at) storage capacity, resulting in lower (or higher) flows downstream from the wetland compared to upstream.

\footnotetext{
${ }^{1}$ Natural Resources Canada, Canadian Forest Service, Northern Forestry Centre, Edmonton, Alberta

${ }^{2}$ Department of Renewable Resources, University of Alberta, Edmonton, Alberta
} 
- Due to widely varying responses to similar precipitation events, initial attempts using simple runoff models were unsuccessful in predicting runoff for the watershed. As a result, a storageeffective drainage runoff model was developed that had more variables and was better at predicting spring snowmelt runoff depths (Holecek 1988).

\section{Post-1994 harvesting results}

- Prior to harvest, water quality in the treated watershed was more favorable for aquatic organisms than in the control watershed; this trend continued even after harvest.

- DOC concentrations and water temperatures were lower in the harvested reach than in the control reach, whereas dissolved oxygen and $\mathrm{pH}$ were higher.

- DOC concentrations decreased downstream from the source to $25 \%$ of source concentration at the watershed outlet.

- DMI harvest plan and operating ground rules required preservation of the riparian zone, which is likely the cause of the lack of change in water quality post-harvest. Thus, DMI should continue to use similar logging operations.
Table 1. Summary of Spring Creek watershed and climatic characteristics

\begin{tabular}{|c|c|}
\hline & Watershed description \\
\hline Location (descriptive) & $\begin{array}{l}350 \mathrm{~km} \text { north of Edmonton in north-central Alberta, at the } \\
\text { south-western edge of the Boreal Forest. }\end{array}$ \\
\hline Location (geographic) & Latitude N $54^{\circ} 53^{\prime} 31^{\prime \prime}$, Longitude W $117^{\circ} 50^{\prime} 54^{\prime \prime}$ \\
\hline Watershed area & $112 \mathrm{~km}^{2}$ \\
\hline Alberta natural regions & $\begin{array}{l}\text { Central Mixedwood subregion of the Boreal Forest Natural } \\
\text { Region }\end{array}$ \\
\hline Elevation range & $610 m-760 m$ \\
\hline Vegetation & $\begin{array}{l}\text { Aspen (Populus tremuloides Michx.) dominated mixedwood } \\
\text { stands, with white spruce (Picea glauca (Moench) Voss) and } \\
\text { black spruce (Picea mariana (Mill.) BSP) }\end{array}$ \\
\hline Precipitation & $540 \mathrm{~mm}$ \\
\hline Runoff* ${ }^{*}$ & $\begin{array}{l}\text { Spring Creek Main: } 80 \mathrm{~mm}(1966-1986) \\
\text { Sub-basins: } \\
\text { Rocky Creek: } 68 \mathrm{~mm}-18.6 \mathrm{~km}^{2} \quad(1967-1987,1993-2003) \\
\text { Bridlebit Creek: } 98 \mathrm{~mm}-19.7 \mathrm{~km}^{2} \quad(1967-1987,1993-2003) \\
\text { Wolverine Creek: } 61 \mathrm{~mm}-11.1 \mathrm{~km}^{2} \quad(1967-1987) \\
\text { Upper Spring Creek: } 96 \mathrm{~mm}-33.4 \mathrm{~km}^{2} \quad(1967-1987) \\
\text { Ungauged Area of Watershed: } 34 \mathrm{~km}^{2}\end{array}$ \\
\hline Temperatures $^{\star *}$ & $\begin{array}{l}\text { Mean annual temperature: } 1^{\circ} \mathrm{C} \\
\text { Daily mean regional temperatures: } \\
\begin{array}{ll}\text { January: }-12{ }^{\circ} \mathrm{C} \\
\text { July: } 16^{\circ} \mathrm{C}\end{array}\end{array}$ \\
\hline
\end{tabular}

\footnotetext{
* N.B. Runoff values calculated from Water Survey of Canada Database as they were not available in original sources (Environment Canada 2010)

** Canadian Climate Normals for Valleyview (Environment Canada 2013)
}

\section{Sediment yield}

- A $1.5 \mathrm{~km}^{2}$ zone of slope instability near the watershed mouth contributed $90 \%$ of the sediment yield for Spring Creek. Seventy-six percent of the annual sediment yield occurs during the spring melt (Martz 1978, Martz and Campbell 1980). Thus harvesting or other disturbances should avoid zones of slope instability to mitigate erosion problems from these naturally unstable areas.

- A pipeline right-of-way was installed in 1977 across Spring Creek near the mouth (Fig. 1). The resulting contributing area for sediment was $0.005 \mathrm{~km}^{2}$ and produced a $36 \%$ increase in sediment yield over a four-month period.

- Sediment rating curves for Spring Creek watershed (at the mouth) produced reasonable predictions of sediment concentrations from streamflow rates.

- A five-year record of suspended sediment and water discharge from Spring Creek watershed and five of its subwatersheds showed that the sub-watersheds accounted for $82 \%$ of its total water yield, but only $8 \%$ of its total sediment yield. The sub-watersheds form $76 \%$ of the total area of the Spring Creek watershed.

- Sediment discharge from Spring Creek watershed was largely independent of the erosional processes operating in the sub-watersheds.
Water yield increases and hydrologic recovery

- Snow accumulation in uncut forest and clear-cuts was the same from 1994 to 1996 (Swanson and Rothwell 2001). Wind speeds $10 \mathrm{~m}$ above the ground surface in clear-cuts were generally less than $2 \mathrm{~km} / \mathrm{hr}$, which is less than threshold velocity for transporting snow particles from a snow pack (Tabler and Schmidt 1972). Average tree height in clear-cuts at end of the first year after harvest was $1 \mathrm{~m}-1.5$ $\mathrm{m}$, which provided aerodynamic roughness to protect shallow snow packs from wind erosion.

- Annual evapotranspiration from 1 to 5 -year-old clear-cuts ranged from $0-143 \mathrm{~mm}$ less than a mature forest on the same site based on 1225 soil moisture measurements and Bowen ratio measurements.

- A paired basin regression analysis was used to assess water yield increases following a 23\% harvest of Rocky Creek. Regression of Rocky Creek and adjacent Bridle Bit Creek showed a high level of correlation $\left(\mathrm{R}^{2}=0.97\right)$. Average water yield increase for five years (1994-1998) in Rocky Creek was $16.3 \mathrm{~mm}$, which was in close agreement to simulated estimates of generated runoff obtained with the Brook90 model (Federer 1995). Hydrologic recovery in Rocky Creek was assumed to occur 45 years after harvest based on simulations with the Brook90 model. 
Table 2. Study design and measured variables for Spring Creek Representative and Experimental Watershed Project

\begin{tabular}{ll}
\hline & Study design \\
\hline Study type & before/after treatment and paired basins \\
Treatments & 1 sub-basin harvested in winter 1993/94 \\
Controls & 1 sub-basin \\
Study duration & 1965-1987; 1992-1999 \\
Variables measured & $\begin{array}{l}\text { precipitation, runoff, snow water equivalent, } \\
\text { suspended sediment, stream discharge, water } \\
\text { quality, water level, temperature, dissolved } \\
\text { oxygen, pH, specific conductance, water } \\
\text { chemistry, dissolved organic carbon }\end{array}$ \\
\hline
\end{tabular}

detained in the wetland, was not. The volume amounted to only $7 \%$ of the combined basin runoff from precipitation and the beaver dam outburst.

- This extreme event showed that beaver activity can greatly affect the hydrology of small streams and demonstrated, together with basin storage studies conducted on the Spring Creek watershed, the importance of taking wetland storage into account when conducting hydrologic studies on watersheds that contain sizeable areas of wetlands.

\section{References}

Environment Canada. 2010. Environment Canada DATA Explorer - HYDAT version 1, http://www.ec.gc.ca/rhc-wsc/default.asp?lang= En\&n=0A47D72F-1

Environment Canada. 2013. Canadian climate normals and averages 1981-2010: Valleyview, Canada's National Climate Archive, http://climate.weatheroffice.gc.ca/climate_normals/

Federer C. A. 1995. BROOK90: A simulation model for evaporation, soil water and streamflow. Version 3.1, Computer freeware and
Effects of catchment characteristics and disturbances on dissolved organic carbon

- The transportation of large amounts of DOC down Rocky Creek was affected directly by events such as high rainfall and beaver dam failure (Hillman et al. 1996, 2004; Hillman 1998).

- Storage of DOC in the catchment was strongly influenced by the presence of wetlands and beaver dams. Organicdebris dams created by a failed dam event served as both sources and sinks for DOC.

- In 1994 and 1995, disturbances occurring during periods of 17 and 28 days accounted for $94 \%$ (1374 $\left.\mathrm{kg} / \mathrm{km}^{2}\right)$ and $84 \%(204$ $\mathrm{kg} / \mathrm{km}^{2}$ ), respectively of the amount of DOC exported from the catchment. DOC concentrations in the stream were greatest $(77.0 \mathrm{mg} / \mathrm{L})$ near the top of the catchment and decreased progressively downstream to the catchment outlet, where the mean concentration was $23.3 \mathrm{mg} / \mathrm{L}$.

- On June 8 1994, a beaver dam failed and released about $7500 \mathrm{~m}^{3}$ of water. The estimated peak of the resulting flood wave was $15 \mathrm{~m}^{3} / \mathrm{s}, 3.5$ times the maximum discharge recorded over 23 years. The flood wave peak was dampened to $6 \%$ of the estimated upstream flow peak as it passed through a 90-ha wetland.

- Although the peak flow resulting from the dam outburst was extreme, the volume, most of which was probably



Fig. 1. Spring Creek watershed; subwatersheds include: Horse Creek (HC), Wolverine Creek (WC), Rocky Creek (RC), Bridlebit Creek (BC), Upper Spring Creek (USC), and Willow Creek (WiC). (Figure from: Martz and Campbell. 1980. Effects of a pipeline right-of-way on sediment yields in the Spring Creek watershed, Alberta. Can. Geotech. J. 17 (3): 361-368.)

documentation. U.S. Department of Agriculture, Forest Service, Northeastern Forest Experiment Station, Durham NH. 104 p.

Hillman, G.R. 1998. Flood wave attenuation by a wetland following a beaver dam failure on a second order boreal stream. Wetlands 18: 21-34.

Hillman, G.R., J.C. Feng and C.C. Feng. 1996. Effects of watershed characteristics and disturbances on the water quality of two Boral streams. Natural Resources Canada, Can. For. Serv., Alberta Environmental Protection. Edmonton, AB. 72 p.

Hillman, G.R., J.C. Feng, C.C. Feng and Y. Wang. 2004. Effects of catchment characteristics and disturbances on storage and export of dissolved organic carbon in a boreal headwater stream. 2004. Can. J. Fish. Aquat. Sci. 61(8): 1447-1460. 
Holecek, G. 1967. Spring Creek watershed investigation. Report No. 1, calendar year 1966. Water Resources Division, Hydrology Branch, Alberta Dept. of Agriculture, Edmonton, Alberta. 37 p.

Holecek, G. 1970. Spring Creek watershed investigation. Report No. 2, calendar years 1967, 1968, 1969. Water Resources Division, Hydrology Branch, Alberta Dept. of Agriculture, Edmonton, Alberta. 194 p.

Holecek, G. 1988. Storage-effective drainage (SED) runoff model. J. Hydrol., 98: 295-314.

Martz, L.W. 1978. The sediment yield of Spring Creek watershed. Report 1978/3. Dep. Geography, Univ. Alberta and Alberta Environ., Res. Secretariat, Edmonton, Alberta. 101p.
Martz, L.W. and I.A. Campbell. 1980. Effects of a pipeline right-ofway on sediment yields in the Spring Creek watershed, Alberta. Can. Geotech. J. 17: 361-368.

Swanson, R.H. and R.L. Rothwell. 2001. Hydrologic recovery of Aspen clearcuts in northwestern Alberta. USDA Forest Service Proceedings. RMRS-P-18. pp. 121-136.

Tabler, R.D. and R. A .Schmidt. 1972. Weather conditions that determine snow transport distances at a site in Wyoming. Proceedings UNESCO/WMO/IAHS Int. Symp. on The Role of Snow and Ice in Hydrology. Banff, Alberta, Canada, September,1972. Vol. 1, 118-127. 